\title{
Konstruksi Realita Sosial City Branding Magelang Kota Sejuta Bunga (MKSB)
}

\author{
Gladi Dwinta Kusuma ${ }^{1}$, Prayudi ${ }^{2}$, Christina Rochayanti ${ }^{3}$ \\ ${ }^{1,2,3}$ Program Studi Magister Ilmu Komunikasi, Universitas Pembangunan Nasional "Veteran" Yogyakarta \\ Jl. Babarsari 2, Tambakbayan, Yogyarta, 55281, Indonesia \\ Email: gladidwintakusuma@gmail.com"; prayudi@upnyk.ac.id²; christina.rochayanti@upnyk.ac.id ${ }^{3}$ \\ * Corresponding author
}

\begin{abstract}
Magelang City is one of the City in Central Java Province that is implementing City Branding Magelang Kota Sejuta Bunga (MKSB) with the slogan MKSB is still considered not to realize this character. This study aims to analyze the reality construction process that has been built in the City of Magelang since eight years carrying out the city branding Magelang Kota Sejuta Bunga in terms of government and in terms of reality in the people of the City of Magelang by using thought through Social Reality Construction Theory. The method used in this research is qualitative method. The theory of social construction of reality and the concept of city branding is the basis for discussing research results. The results showed that the incompatibility of government understanding and communication with the people of the City of Magelang in the City Branding Magelang Kota Sejuta Bunga (MKSB). Lack of detention of the people of the City of Magelang against the construction built by the government of the City of Magelang. Thus, the City Branding MKSB activities carried out in the City of Magelang for 8 years are considered to still need an approach and communication to the community, especially the people of the City of Magelang. The contribution of this research is in the form of recommendations for new strategies to the government to pay attention to important keys in the form of attention, communication, and public concern in order to realize MKSB city branding. Keywords: City Branding Magelang; Magelang Kota Sejuta Bunga (MKSB); Social Reality Construction Theory
\end{abstract}

\begin{abstract}
Abstrak
Kota Magelang merupakan salah satu Kota di wilayah Provinsi Jawa Tengah yang sedang melaksanakan city branding Magelang Kota Sejuta Bunga (MKSB) dengan slogannya MKSB masih dianggap belum mewujudkan karakter. Penelitian bertujuan untuk menganalisis proses konstruksi realita yang telah dibangun di Kota Magelang sejak delapan tahun melaksanakan city branding Magelang Kota Sejuta Bunga dari segi pemerintahannya dan segi secara realitas pada masyarakat Kota Magelang dengan menggunakan pemikiran melalui Teori Konstruksi Realitas Sosial. Metode yang digunakan dalam penelitian ini adalah metode kualitatif. Teori konstruksi sosial atas realitas dan konsep city branding menjadi landasan dalam membahas hasil penelitian. Hasil penelitian menunjukkan bahwa tidak selarasnya pemahaman dan komunikasi pemerintah terhadap masyarakat Kota Magelang dalam City branding Magelang Kota Sejuta Bunga (MKSB). Kurangnya pemahanan masyarakat Kota Magelang terhadap konstruksi yang dibangun oleh pemerintah Kota Magelang. Kegiatan City branding MKSB yang dilaksanakan di Kota Magelang selama 8 tahun ini dianggap masih perlu adanya pendekatan dan komunikasi kepada masyarakat, khususnya masyarakat Kota Magelang. Kontribusi penelitian ini berupa rekomendasi stategi baru kepada pemerintah untuk memerhatikan kunci penting berupa perhatian, komunikasi, dan kepedulian masyarakat agar dapat mewujudkan city branding MKSB. Kata kunci: City Branding Magelang; Magelang Kota Sejuta Bunga (MKSB); Teori Konstruksi Realitas Sosial
\end{abstract}

\section{Pendahuluan}

Kota merupakan fasilitator dan sebagai saluran komunikasi yang penting bagi pertumbuhan ekonomi, peningkatan produktivitas dan peningkatan pendapatan penduduk di negara maju dan negara berkembang (Quieqley, 2009:116). Kota menjadi dominan karena pembangunan infrastruktur fisik, infrastruktur sumberdaya manusia, dan infrastruktur teknologi dan komunikasi (ICT) yang terjadi hampir secara bersamaan. Sebuah kota dapat berkembang menjadi kota berbasis pengetahuan, jika kota itu mampu menarik dan berkomunikasi dengan orang-orang yang berbakat, membangun budaya toleransi, memiliki komunikasi dengan dunia luar serta dalam, memiliki citra dan reputasi. 
Berdasarkan kebutuhan sebuah Kota, dalam konteks pengembangan spasial, banyak pemerintah kota yang mencoba meningkatkan daya tarik kota, dan berusaha menghasilkan inovasi kebijakan seperti pembangunan properti baru sebagai "flagship" kota. Perwujudan dari flagship itu menjadi tuan rumah kegiatan olah raga dan budaya, festival pameran, serta city branding. Menurut President dan CEO PATA Indonesia Chapter, Purnomo Siswoprasetijo dalam seminar yang diselenggarakan Kementerian Pariwisata RI, menyatakan bahwa city branding merupakan suatu strategi yang dilakukan negara atau daerah untuk membuat positioning yang kuat dalam target pasar mereka. Seminar ini menghasilkan pemikiran dan terobosan baru dalam pengembangan industri pariwisata khususnya melalui penerapan strategi "City Branding".

Kota Magelang merupakan Kota kecil yang sedang melaksanakan city branding sejak tahun 2011 hingga 2020 dan saat ini masih berlangsung, mengawali sejarahnya sebagai desa perdikan Mantyasih, yang saat ini dikenal dengan Kampung Meteseh di Kelurahan Magelang. Guna mengomunikasikan daerahnya, Kota Magelang harus memiliki perencanaan pembangunan yang baik. Perencanaan pembangunan daerah merupakan satu kesatuan dalam sistem perencanaan pembangunan nasional, yang disusun dalam jangka panjang, jangka menengah dan jangka pendek, oleh karena itu untuk memberikan arah dan tujuan dalam mewujudkan cita-cita dan tujuan daerah sesuai dengan visi, misi dan arah kebijakan daerah (Chaerani, 2011). Kelebihan tata letak yang dimiliki oleh Kota Magelang yang dilalui oleh jalur arteri primer yang menghubungkan Kota Semarang, Yogyakarta, Purwokerto, Salatiga, Temanggung, dan Wonosobo. Selain itu, dari kota-kota besar juga cukup mudah karena Kota Magelang terletak pada sisi luar segitiga Kota Semarang, Yogyakarta, dan Surakarta, dimana pada ketiga kota besar tersebut terdapat bandara Internasional tersebut seharusnya mampu dimanfaatkan dengan baik oleh Kota Magelang untuk mengomunikasikan dan meningkatkan perekonomiannya melalui place branding yang positif.
Realitasnya yang terjadi di Kota Magelang adalah Kota Magelang masih dianggap sebagai sebuah kota yang belum memiliki karakter atau identitas yang menarik. Berawal sejak Magelang sebagai Magelang Kota Harapan cukup lama. Pemerintah Kota Magelang berusaha mengomunikasikan karakter daerah dengan menggunakan city branding Magelang Kota Harapan hingga tahun 2010, perubahan branding Kota Magelang dari Magelang Kota Harapan menjadi Magelang Kota Sejuta Bunga didasari oleh perubahan kepemimpinan di Kota Magelang. Sejak tahun 2011 hingga saat ini 2019, Kota Magelang melalui wujud City Branding dengan slogannya Magelang Kota Sejuta Bunga (MKSB) masih dianggap belum mewujudkan karakter ini (Juanim \& Rahmawati, 2015).

Konsep Kota Magelang sebagai Kota Bunga didasari atas Taman Kyai Langgeng yang dulunya bernama "taman bunga" merupakan objek wisata yang, menjadi andalan Kota Magelang, dan sejak jaman Belanda Kota Magelang yang sudah dikenal sebagai kota bunga. Antara lain disebut Tuin Van Java (Taman di Pulau Jawa), Paradijs Van Java (Surganya Pulau Jawa) dan Het Central Park Van Java (Taman di Tengah Pulau Jawa). Hasil pra survei pada beberapa masyarakat Kota Magelang, dan mayoritas masyarakat Kota Magelang mengatakan bahwa Kota Magelang masih belum mampu mewujudkan branding sebagai Magelang Kota Sejuta Bunga. City Branding sering terjebak sekedar pada aktivitas yang sifatnya artifisial. Misalnya membuat jargon tetapi tidak relevan dengan karakteristik kota atau tidak mengintegrasikan jargon tersebut dengan master plan pembangunan kota seperti kota Magelang yang sudah beberapa kali berganti. Menurut Kavaratzis (2004) penggunaan jargon, iklan, humas, dan sejenisnya itu adalah tahapan kedua atau sekunder dari proses City branding. Tahapan utama atau primer adalah justru pada pengelolaan ruang, perilaku masyarakat lokal, infrastruktur, dan struktur organisasi dan tahap terakhir adalah tahap menjalankan yang telah 
direncanakan. Berdasarkan latar belakang diatas maka tahapan menurut Kavaratzis (2004) merupakan tahapan yang digunakan pada penelitian ini untuk menganalisa dan melacak gagasan city branding yang dijalankan oleh Kota Magelang, dan menganalisis strategi yang dijalankan oleh Kota Magelang dalam melaksanakan city branding dari segi level ide, pelembagaannya, dan prakteknya.

Pada penelitian ini, peneliti menggunakan teori konstruksi realita sosial dan konsep city branding sebagai landasan dalam penelitian. Teori konstruksi realita sosial atas realita melihat bagaimana fenomena yang terjadi seharian mengkonstruksi realita sosial melalui sebuah kemapuan individu dalam memahami lingkungan sosialnya, dan bagaimana Kota Magelang menciptakan atau mengkonstruksi potensi yang ada demi mewujudkan City branding yang berlangsung di Kota Magelang. Analisa yang dilakukan pada penelitian ini didasari oleh teori yang dicetuskan oleh Peter L. Berger dan Thomas Luckmann yaitu Teori Konstruksi Realitas Sosial. Teori ini digunakan sebagai acuan dan dasar pemikiran dalam setiap pemikiran yang dilakukan oleh peneliti.

Proses sosial melalui tindakan dan interaksi dimana individu atau sekelompok individu (masyarakat), menciptakan secara terus-menerus suatu realitas yang dimiliki dan dialami bersama secara subjektif merupakan istilah dari kontruksi sosial yang secara realita berlangsung sehari-hari dalam melaksanakan program city branding. Pada penelitian ini melihat bagaimana konstruksi realita sosial City branding kota Magelang dengan tujuan melihat latar belakang dari pelaksanaan City branding Kota Magelang serta menganalisis dan melacak gagasan city branding yang dijalankan oleh Kota Magelang, dan menganalisis strategi yang dijalankan oleh Kota Magelang dalam melaksanakan city branding dari segi level ide, pelembagaannya, dan prakteknya.

\section{City Branding}

Konsep atau teori yang mendukung perancangan strategi city branding adalah teori komunikasi dalam hal ini komunikasi pemasaran serta merek yang kemudian dikenal dengan istilah branding. Aaker (2014) menjelaskan "ketika brand dianggap sebagai aset, peran manajemen brand berubah secara radikal dari taktis dan reaktif menjadi strategis dan visioner. Manajemen brand juga menjadi lebih luas dan mencakup hal-hal seperti pandangan strategis terhadap pasar, stimulasi dari inovasiinovasi "besar", strategi pertumbuhan, strategi portfolio brand, dan strategi brand global". Anholt (2007) mendefinisikan city branding sebagai bagian dari kajian ilmu komunikasi terutama sebagai fungsi public relations yaitu dengan mengartikan city branding sebagai manajemen citra suatu destinasi melalui inovasi strategis serta koordinasi ekonomi, komersial, sosial, kultural, dan peraturan pemerintah.

Pengertian ini diperkuat dengan pendapat lain yang dicetuskan oleh Kavaratzis (2004) yang mengungkapkan bahwa city branding umumnya memfokuskan pada pengelolaan citra, tepatnya apa dan bagaimana citra itu dibentuk serta aspek komunikasi yang dilakukan dalam proses pengelolaan citra. Menurut Sugiarsono (2009: hal 130) dalam membuat sebuah city branding, terdapat beberapa kriteria yang harus dipenuhi, diantaranya: a) Attributes, city branding yang dibuat harus sesuai dengan karakter, serta potensi yang dimiliki oleh Kota, sehingga city branding yang dibuat dapat mewakili potensi dari Kota itu sendiri; b) Message, tugas dari sebuah City branding adalah menyampaikan pesan berupa citra yang dimiliki oleh sebuah Kota, pesan disini haruslah mudah diingat oleh penerima pesan branding itu sendiri. Kesan pintar dan menyenangkan dalam sebuah city branding juga harus ada, sehingga dapat lebih memudahkan lagi penerima pesan untuk mengingatnya; c) Differentiation, keunikan menjadi unsur yang 
sangat penting dalam pembuatan sebuah city branding Karena hal tersebut juga menjadi pembeda dengan city branding yang telah ada sebelumnya; dan d) Ambassadorship, hal yang penting dari suatu city branding adalah menarik orang untuk hadir dan tinggal di sebuah Kota. Menginsipirasi orang-orang untuk datang dan ingin tinggal di kota tersebut.

\section{Kota}

Kota adalah pusat kehidupan yang dapat dilihat dari berbagai macam sudut pandang pendekatan. Aspek tersebut memberikan gambaran bahwa kota menjadi tempat masyarakat berperilaku untuk mengisi aktifitas kehidupannya sehari-hari. Dengan perilaku tersebut dapat dilihat melalui sosiologi maupun antropologinya, atau dapat juga dilihat dari aspek fisik perkotaan yang memberikan kontribusi pada perilaku (manusia dan struktur sosialnya). Pada bagian lain, Nas (1986:14) menegaskan, bahwa kota itu adalah suatu lingkungan material buatan manusia, suatu pusat produksi, suatu komunitas sosial, suatu komunitas budaya, dan suatu masyarakat terkontrol.

\section{Teori Kontruksi Realita Sosial}

Konstruksi Sosial atas Realitas (Social Construction of Reality) didefinisikan sebagai proses sosial melalui tindakan dan interaksi dimana individu atau sekelompok individu, menciptakan secara terus-menerus suatu realitas yang dimiliki dan dialami bersama secara subjektif. Konstruksi sosial merupakan teori sosiologi kontemporer, yang dicetuskan oleh Peter L. Berger dan Thomas Luckmann. Berger dan Luckman berpendapat bahwa institusi masyarakat tercipta dan dipertahankan atau diubah melalui tindakan dan interaksi manusia, walaupun masyarakat dan institusi sosial terlihat nyata secara obyektif, namun pada kenyataannya semua dibentuk dalam definisi subjektif melalui proses interaksi (Sulaiman, 2016).
Fokus teori-teori dalam paradigma ini adalah pola interaksi antarindividu yang prosesnya melibatkan makna, peran, aturan, dan nilai-nilai budaya. MenurutJames Carey, social construction umumnya dipahami dengan menggabungkan empat tahapan: 1) Construction, Aktor sosial mengembangkan konsep bagaimana itu menjadi kenyataan. Pengetahuan biasanya masih bersifat tidak kelihatan atau invisible; 2) Maintenance, orang perlu aktif memelihara konstruksi sosial agar tetap terus berjalan. Jika tidak relevan lagi, konstruksi sosial tersebut mencair dan diabaikan. Jadi, makna sosial berubah atau mencair kalau tidak dijaga; 3) Repair, perbaikan aktor sosial (social actors). Orang perlu memperbaiki konstruksi karena aspekaspeknya mungkin dilupakan, berubah seiring perjalanan waktu; dan 4) Change, ada beberapa kali, konstruksi yang berjalan dalam satu waktu mengirimkan pesan yang tak lagi didukung. Jadi perlu perubahan untuk generasi berikutnya.

Teori konstruksi realita sosial pada penelitian ini melihat bagaimana fenomena city branding yang terjadi di Kota Magelang dalam keseharian mengkonstruksi realita sosial melalui sebuah kemapuan individu dalam memahami lingkungan sosialnya, dan bagaimana kota Magelang menciptakan atau mengkonstruksi potensi yang ada demi mewujudkan City branding yang berlangsung di Kota Magelang. Asumsi dasar dari pemikiran konstruktivisme, yaitu: pertama, suatu kejadian realita tidak hadir dengan sendirinya secara objektif, tetapi diketahui dan dipahami melalui pengalaman. Kedua, realitas dipahami dengan menggunakan kategori bahasa secara situasional yang tumbuh dan berkembang dari interaksi sosial di dalam suatu kelompok sosial pada saat dan tempat tertentu. Ketiga, bagaimana suatu realitas dapat dipahami, ditentukan pada konvensi (kesepakatan) komunikasi yang dilakukan pada saat itu. Keempat, pemahaman dengan realitas yang tersusun secara sosial membentuk beberapa aspek penting lain dari kehidupan 
(Sendjaja, 1994:325-326). Hal tersebut memiliki arti ketika kita berpikir dan berperilaku dalam kehidupan bermasyarakat pada kehidupan sehari-hari, pada dasarnya merupakan persoalan tentang bagaimana kita memahami realitas yang kita hadapi di lingkungan sosial.

Penjelasan Berger dan Luckman tentang Teori ini yaitu diwujudkan dengan sebutan sebuah momen. Momen itu memiliki tiga tahapan dealetika konstruksi realitas didalamnya yang terjadi melalui eksternalisasi, objektivasi, dan internalisasi. Kesimpulan dari penjelasan Berger dan Luckman (Bungin, 2008) menilai bahwa realitas tidak dibentuk secara alami, tetapi sebaliknya, dibentuk dan dikonstruksi.

Penelitian ini memiliki tujuan untuk mengananlisis proses penciptaan brand di Kota Magelang, menganalisa fenomena city branding yang terjadi di Kota Magelang dalam keseharian mengkonstruksi realita sosial melalui sebuah kemampuan individu dalam memahami lingkungan sosialnya, dan mengidentifikasi bagaimana Kota Magelang menciptakan atau mengkonstruksi potensi yang ada demi mewujudkan City branding yang berlangsung di Kota Magelang.

\section{Metode Penelitian}

Jenis penelitian dalam penelitian ini adalah penelitian kualitatif dengan menggunakan metode analisis deskriptif dengan pendekatan konstruktivisme. Penelitian deskriptif adalah penelitian yang memaparkan situasi atau peristiwa, dan tidak mencari atau menjelaskan hubungan, tidak menguji hipotesis atau membuat prediksi. Beberapa penulis memperluas penelitian deskriptif kepada segala penelitian selain penelitian historis dan eksperimental (Rakhmat, 2001:36).

Sumber data primer adalah sumber data yang diperoleh langsung dari responden atau objek yang diteliti. Data primer dikumpulkan dari para responden kunci (key respondents) antara lain keterangan atau informasi dari masyarakat setempat yang berpartisipasi langsung dalam city branding MKSB Kota Magelang. Data sekunder pada penelitian ini diperoleh dari buku serta materi tertulis yang relevan dengan tujuan penelitian. Data-data tersebut digunakan sebagai refrensi untuk mendukung data primer dalam melakukan penelitian. Teknik pengumpulan data yang digunakan adalah melalui observasi, wawancara mendalam dan dokumentasi terkati city branding MKSB Kota Magelang. Teknik analisis data (Noveline, Lestari, \& Susilo, 2014) dilakukan dengan: mereduksi data dengan membatasi dengan permasalahan penelitian; menyajikan data dalam bentuk deskriptif, serta penarikan kesimpulan mengenai city branding MKSB.

\section{Hasil Penelitian dan Pembahasan}

Branding daerah yang dilakukan oleh Kota Magelang memiliki tujuan untuk mempromosikan daerah beserta brand daerah, meningkatan kunjungan wisata maupun bisnis di Daerah dan meningkatkan citra (image) dan daya saing Daerah. Penetapan branding daerah yang sedang terlaksana di Kota Magelang dimaksudkan untuk menjamin keberlanjutan dan konsistensi Walikota dan Wakil Walikota dalam menerapkan Magelang Kota Sejuta Bunga sebagai Branding di Daerah; dan memberikan payung hukum dalam pelaksanaan Branding di Daerah. Kota Magelang, memiliki berbagai potensi yang digunakan dalam mengembangkan city branding. Budaya, kuliner dan kawasan menjadi potensi yang dimanfaatkan untuk menyukseskan city branding MKSB di Kota Magelang. Hasil yang diperoleh peneliti melalui berbagai sumber dibagi menjadi kedalam 3 aspek, aspek fisik, aspek ekonomi dan aspek sosial budaya.

\section{Aspek Fisik, Ekonomi, dan Sosial Budaya City Branding MKSB Kota Magelang}

Pelaksanaan MKSB dalam aspek Fisik yang terkonstruksi adalah 6 (enam) sasaran yaitu tertatanya kawasan (district) kampung organik, terwujudnya peningkatan pengelolaan lingkungan hidup, tertatanya kawasan (district) 
kantor pemerintahan dan fasilitas sosial atau umum tertatanya Landmark Kota Sejuta Bunga, tertatanya taman simpul kota (nodes), terpublikasinya Magelang Kota Sejuta Bunga.

Aspek ekonomi, terdapat 10 (sepuluh) sasaran yang dicapai melalui MKSB. Sepuluh sasaran dalam aspek ekonomi tersebut, yaitu: 1) terwujudnya agribisnis tanaman hias dan bunga sebagai salah satu penggerak ekonomi masyarakat Kota Magelang; 2) terwujudnya peningkatan kerjasama antara pemerintah daerah dan swasta dalam pelaksanaan pembangunan MKSB; 3) terwujudnya peningkatan investasi PMA/PMDN; 4) terwujudnya peningkatan kerjasama antara pemerintah daerah dan swasta dalam pelaksanaan pembangunan MKSB; 5) terciptanya iklim investasi yang kondusif; 6) terwujudnya peningkatan skill dan pengetahuan pencari kerja dalam berwirausaha; 7) terwujudnya peningkatan penyerapan tenaga kerja melalui pembangunan MKSB; 8) terwujudnya peningkatan jumlah UMKM yang mendukung MKSB; 9) terwujudnya peningkatan kemampuan pedagang sektor informal dalam memberikan pelayanan dan kenyamanan bagi pengunjung atau wisatawan; dan 10) Tertatanya PKL sesuai dengan RT atau RW.

Aspek sosial dan budaya, ada 7 (tujuh) sasaran yang dicapai melalui MKSB, yaitu: 1) aparatur pemerintah yang handal dan profesional dalam memberikan pelayanan publik; 2) terwujudnya peningkatan pemberdayaan perempuan dalam pembangunan MKSB; 3) terwujudnya peningkatan partisipasi masyarakat Kota Magelang dalam mendukung programprogram MKSB; 4) terwujudnya payung hukum bagi pelaksanaan pembangunan MKSB; 5) terwujudnya peningkatan minat masyarakat dalam membaca dan menulis artikel yang bertemakan MKSB; 6) terdokumentasinya penyelenggaraan pembangunan MKSB, dan 7) terwujudnya peningkatan jumlah kunjungan wisatawan lokal maupun asing.
Tahapan Konstruksi City Branding Magelang Kota Sejuta Bunga (MKSB)

Langkah-langkah spesifik dalam membangun city branding yang dilaksanakan oleh pemerintah Kota Magelang tersebut diadaptasi dari langkah membangun brand untuk produk dan jasa, dengan merubah subjek branding dari sebuah produk menjadi sebuah wilayah atau kota. Langkah-langkah utama dalam membangun city branding yang dilakukan oleh pemerintahan Kota Magelang adalah sebagai berikut:

\section{Mapping Survey}

Survey persepsi merupakan tahap awal konstruksi city branding yang dilakukan oleh pemerintah Kota Magelang. Berdasarkan ide dan gagasan yang diberikan atau dimunculkan dalam sebuah forum resmi. Gagasangagasan yang muncul diseleksi dan disurvey dengan kecocokan pada Kota Magelang mulai segi fisik, sosial-budaya dan ekonomi masyarakat Kota Magelang, yang secara rinci dilaksanakan survei klimatologi, geologi, geografi, topografi, dan kependudukannya.

Walikota Kota Magelang sebagai pencetus ide Magelang sebagai Kota Bunga, hingga saat ini masih dalam tahap perwujudan, pada awalnya juga disesuaikan dengan keadaan Kota Magelang. Timbul berbagai pertanyaan, apakah Kota Bunga cocok bagi masyarakat Kota Magelang? Apakah Kota Bunga dapat diwujudkan dilingkungan Kota Magelang? Bagaimana mewujudkannya? Untuk menjawab pertanyaan tersebut Badan Perencanaan Pembangunan Daerah Kota Magelang melaksanakan berbagai survei terkait kemampuan Kota Magelang.

\section{Event Kota Magelang sebagai Pendukung Pelaksanaan City Branding MKSB di Kota Magelang}

Selain dengan usaha mewujudkan city brandingKotaMagelang MKSB, pemerintahKota Magelang juga mengadakan berbagai kegiatan sebagai sarana memperkenalkan city branding MKSB diluar Kota Magelang. Mengadakan 
progam Tahunan AYO KE MAGELANG! program ini bertujuan sebagai sarana MKSB agar lebih dikenal oleh masyarakat ataupun wisatawan yang datang ke Kota Magelang.

Program Ayo Ke Magelang! ini didalamnya terdapat berbagai kegiatan, mulai dari kuliner, pawai atau karnaval, grebeg gethuk, dan bermacam-macam kegiatan lainnya. Pada tahun 2020 Program Ayo Ke Magelang diadakan kembali dengan lebih terkonsep, konsep program ini dirancang agar sesuai dengan karakter masyarakat Kota Magelang. Program Ayo Ke Magelang untuk selanjutnya berganti nama menjadi Magelang Moncer Serius (Modern, Cerdas, Sejahtera, dan Religius). Moncer Serius 2020 merupakan program lanjutan dari Ayo Ke Magelang 2015. Progam ini diadakan sebagai upaya meningkatkan kunjungan wisatawan dan lama tinggal di Kota Magelang. Program Moncer Serius ini berisikan 46 event kegiatan dalam setahun ini.

Program ini memiliki tagline "SPIRIT UNTUK BERKEMBANG DAN SENANTIASA BERSINAR CEMERLANG", secara konsep visual memiliki arti semarak pagelaran, ikon dan landmark Kota Magelang, dan Huruf M sebagai inisial Kota Magelang. Warna yang digunakan mengacu pada konsep modern, dinamis, gembira dan optimis. Warna-warni sebagai bentuk visualisasi perayaan dan keceriaan. Maksud dari program ini adalah untuk mempromosikan Kota Magelang dan memperkuat fungsi Magelang sebagai kota jasa.

\section{Konstruksi Realitas Sosial City Branding Magelang Kota Sejuta Bunga pada Masyarakat Kota Magelang}

Objek pada penelitian ini adalah Kota Magelang dengan subyek penelitiannya adalah pemerintahan, masyarakat dan komunitas yang ada di Kota Magelang sebagai elemen penting selain pemerintah sebagai koordinator atau perencana dalam melaksanakan city branding. Pada penelitian ini, peneliti menganalisa bagaimana city branding MKSB di benak masyarakat Kota Magelang.
Peneliti menelusuri menggunakan wawancara mendalam kepada masyarakat Kota Magelang yang peneliti pilih secara acak. Setelah melaksanakan wawancara mendalam terhadap masyarakat, diperoleh hasil bahwa beberapa masyarakat paham dengan yang sedang dilaksanakan pemerintah Kota Magelang. Respon masyarakat sangat beragam, namun peneliti melihat bagaimana individu memahami MKSB yang sudah berlangsung dimasyarakat.

Pemerintahan Kota Magelang memiliki harapan yang besar terhadap keberhasilan city branding Kota Magelang. Pemerintah tetap berusaha mewujudkan Kota Magelang sebagai Kota yang memiliki karakter kuat dan dapat dikenal oleh Kota-kota lain bahkan luar Negeri sebagai Kota yang asri, nyaman dan indah layaknya sebuah taman bunga. Usaha pemerintah dalam mewujudkan keberhasilan Kota Magelang tidak lepas dari peran masyarakat sebagai pendukung dan penggerak visi Kota Magelang.

Hasil wawancara yang dilakukan oleh peneliti guna mengetahui keterlibatan masyarakat terhadap aktivitas city branding, dapat disimpulkan sangatlah minim. Banyak masyarakat yang mendukung dan mengetahui beberapa kegiatan yang diadakan oleh pemerintah dalam mewujudkan city branding, namun keterlibatan dalam menjaga kelestarian dan menjaga konstruksi yang telah dibangun oleh pemerintah masih sangat kurang.

Observasi dan wawancara yang dilakukan oleh peneliti menyajikan realitas yang ada dimasyarakat. Tiga kecamatan yang ada dikota Magelang hanya beberapa daerah yang mendukung city branding kota Magelang, hal tersebut dapat terlihat melalui beberapa daerah yang berusaha mengimbangi usaha pemerintah dengan memperindah daerah mereka. Berbagai daerah di Kota Magelang. wujud tersebut merupakan bentuk dari pemahaman dan tindakan lanjutan masyarakat Kota Magelang yang memiliki pemahaman yang sama dengan pemerintah terhadap city branding MKSB di 
Kota Magelang. Dengan kata lain maksud dan tujuan dari Konstruksi city branding MKSB yang dibangun oleh pemerintah diterima oleh stakeholder. Komunikasi pemerintah terhadap masyarakat mendapatkan feedback dan respond dan keikutsertaan dalam mencoba menjaga lingkungan agar Kota Magelang tetap indah dan nyaman. Namun, masih banyak masyarakat Kota Magelang yang masih belum paham dengan city branding Kota Magelang. Beberapa dari masyarakat Kota Magelang masih bingung terhadap karakter Kota Magelang. Beberapa narasumber masih melihat Kota Magelang sebagai Magelang Kota Harapan, Magelang sebagai Kota Jasa, dan yang terbaru Magelang Moncer Serius. Mereka tidak memahami maksud dari pemerintah.

Secara realitas peneliti melihat terlalu banyak slogan lama yang masih digunakan baik oleh masyarakat dan oleh pemerintah itu sendiri. Slogan slogan baru untuk jenis kegiatan lain muncul membuat masyarakat sulit membedakan. Peneliti memberikan pertanyaan secara spontan kepada beberapa masyarakat Kota Magelang tentang tagline beberapa Kota, ketika sampai pada Kota Magelang, masih banyak yang menjawab Magelang Kota Jasa, Magelang Kota Harapan, Magelang Kota Sejuta Bunga, Magelang Kota Bunga, Magelang Kota Tua dan Magelang MoncerSerius. Pada spontan wawancara ini, peneliti menemukan beberapa masyarakat Kota Magelang menyebutkan Magelang Moncer Serius sebagai tagline Kota Magelang. Peneliti melihat program yang diadakan pemerintah guna meningkatkan wisatawan ini justru membuat masyarakat Kota Magelang bingung terhadap karakter yang dibangun pada program city branding Kota Magelang.

Beberapa masyarakat yang peneliti wawancara secara acak mengangap Moncer Serius sebagai tagline baru Kota Magelang. Hal ini bisa terjadi dikarenakan memang masih baru terpublis dan masih kurangnya sosialisai pemahaman mengenai progam
Magelang Moncer Serius. Hasil wawancara ini bisa menjadi garis merah pemerintah Kota Magelang dalam memberikan trobosan-trobosan baru dalam usaha mewujudkan City branding di Kota Magelang. Komunikasi pemerintah terhadap masyarakatnya perlu waktu intensif.

Sebelum program Magelang Moncer Serius ini dimunculkan, secara realitas yang diterima masyarakat atau masyarakat memaknai city branding MKSB di Kota Magelang memiliki beragam pendapat, namun peneliti melihat berdasarkan hasil wawancara dan observasi yang peneliti laksanakan, sebagian besar masyarakat Kota Magelang yang peneliti pilih secara acak dengan mengesampingkan pendidikan masih belum dapat memiliki satu pemikiran dengan pemerintah Kota Magelang. Sebagian masyarakat yang memang dilibatkan dan memiliki peranlah yang mempunyai kesamaan memaknai city branding Kota Magelang dengan pemerintah.

Penelitian ini menggunakan teori konstruksi sosial Peter Berger. Titik tekan teori konstruksi realitas sosialadalahmembahas proses bagaimana individu membangun pemahaman bersama mengenai makna. Sesuai dengan pusat perhatian dari konstruksi sosial adalah membangun sesuatu, memiliki sesuatu, atau menciptakan sesuatu menjadi ada dari yang sebelumnya tidak ada. Hasil analisa social construction city branding MKSB di Kota Magelang menurut James W. Carey, adalah sebagai berikut:

\section{Konstruksi (Construction)}

Dalam mengkonstruksi city branding MKSB di Kota Magelang peneliti menganalisa dengan memasukan tahapan konstruksi yang dilakukan oleh pemerintah dengan menggunakan 3 tahap Kavaratziz, secara konseptual, structural dan operasionalnya. Pada tahap Konseptual city branding Kota Magelang sebagai Kota Sejuta Bunga, ide city branding tersebut muncul melalui ide Wali Kota Magelang Ir. H. Sigit Widyonindito, M.T. yang disampaikan kepada pemerintahan Kota Magelang. Beliau ingin Magelang yang 
dahulu kala ketika jaman Belanda masih menduduki Magelang sudah dikenal secara luas dengan sebutan Tuin Van Java (Taman di Pulau Jawa), Paradijs Van Java (Surganya Pulau Jawa) dan Het Central Park Van Java (Taman di Tengah Pulau Jawa) kembali menjadi karakter bagi Kota Magelang melalui city branding Kota Magelang.

Usaha-usaha dibangun di Kota Magelang berawal dari menyusun masterplan city branding Kota Magelang per periode. Periode 2011-2014 merupakan periode pertama sejak beliau menjabat sebagai Kota Magelang. Pada periode ini merupakan periode awal perubahan dari branding Magelang sebagai Magelang Kota Harapan ke Magelang Kota Sejuta Bunga. Tahun-tahun ini merupakan tahun dimana pemerintahan Kota Magelang mengatur dan mewujudkan city branding Kota Magelang, berbagai pro dan kontra diberikan untuk mengkritik Kota Magelang, namun hingga saat ini Kota Magelang mampu bertahan dan terus memberikan yang terbaik dalam mewujudkan Kota Magelang menjadi Kota Sejuta Bunga.

Periode selanjutnya yaitu Masterplan City branding MKSB periode 2014-2018 adalah melanjutkan, memperbaiki, dan menambahkan segala bentuk untuk mewujudkan tujuan city branding Kota Magelang. Pada periode ini pemerintahan Kota Magelang mulai menambahkan sasaran- sasaran seperti yang telah disebutkan dalam hasil penelitian. Pada periode ini Kota Magelang semakin terlihat wujudnya sesuai dengan yang diharapkan. Tahun 2018 merupakan tahun akhir pelaksanaan dokumen MasterplanMagelang KotaSejutaBunga(MKSB) Tahun 2014-2018 sehingga telah dievaluasi atau direview secara keseluruhan bagaimana capaian rencana aksi pembangunan fisik, ekonomi dan sosial budaya terkait dengan pencapaian Magelang Kota Sejuta Bunga (MKSB). Berdasarkan uraian tersebut, maka penyusunan Masterplan City Branding Magelang Kota Sejuta Bunga (MKSB) Tahun 2014-2018 yang akan menjadi bahan masukan dalam perumusan kebijakan dan penyusunan
Masterplan Magelang Kota Sejuta Bunga (MKSB) periode selanjutnya yakni tahun 20192023 yang terintegrasi dengan perencanaan yang termuat dalam RPJMD Kota Magelang Tahun 2016-2021 dan RPJMD Kota Magelang Tahun 2022-2027 sehingga sinergitas antar dokumen perencanaan tersebut bisa tercapai yang didukung oleh seluruh perangkat daerah dan stakeholders terkait dalam rangka pelaksanaan dan pengembangan City branding Magelang Kota Sejuta Bunga (MKSB). Tidak hanya Kota Magelang kaya akan tumbuhan Bunga yang bermekaran, maksud dari Sejuta bunga pada city branding MKSB adalah sebagai kota yang nyaman bagi masyarakat Kota Magelang, Kota yang memiliki keindahan lingkungan yang didalamnya berisi kebersihan dan sejuk udaranya.

Kedua, tahap Struktural, peneliti melihat keterkaitan interaksi secara realitas antara masyarakat Kota Magelang, pemerintah Kota Magelang dan Komunitas (berbagai UKM, Komunitas Toea Kota Magelang) di Kota Magelang dalam memaknai city branding yang sedang berlangsung di Kota Magelang. Proses interaksi terlihat antar pelaku city branding. Interaksi terlihat pada berbagai kesempatan, peneliti melihat pemerintah Magelang mengomunikasikan berbagai informasi baru seputar perkembangan city branding Kota Magelang. Interaksi terjadi ketika saling memberikan pendapat sehingga terbentuk interaksi sosial dalam melaksanakan program city branding di Kota Magelang. Pada tahap struktural ini terjadi dialektika komunikasi antar pelaku city branding. Bukti terjadi dialektika komunikasi dibuktikan dengan interaksi antar individu kepada orang banyak (masyarakat) yang saling memaknai. Sarana interaksi sosial yang digunakan oleh pemerintah adalah dengan mengadakan sosialisasi, Focus Group Discussion (FGD) seperti yang peneliti hadiri pada tanggal 28 dan 29 November 2019, selain pertemuan resmi, kunjungan atau monitoring lapangan yang dilakukan oleh pemerintahan Kota Magelang juga sebagai sarana dalam berkomunikasi. 
Ketiga, tahap Operasional, peneliti menganalisa konstruksi-konstruksi realitas yang sudah dibangun dan berlangsung dalam membangun dan melaksanakan city branding Magelang Kota Sejuta Bunga (MKSB). Peneliti menemukan berbagai macam bangunan yang memang disesuaikan dan diatur dengan rapi dan indah. Seperti taman-taman Kota yang dibangun pada lokasi tertentu. Pada tahap ini peneliti melihat usaha pemerintah dalam mewujudkan dan mempublikasikan segala macam bentuk atau konstruksi yang telah dibangun untuk city branding Kota Magelang. Pemerintah dan masyarakat bersama mempublikasikan bentuk keindahan Kota Magelang.

Teori konstruksi sosial atas realita berusaha melihat bagaimana fenomena keseharian mengkonstruksi realita sosial melalui sebuah kemampuan dalam memahami lingkungan sosial. Satu hal yang penting (Bungin, 2017) tentang konstruksi sosial adalah bahwa nilai dan norma dikonstruksi secara objektif. Kegiatan city branding Kota Magelang yang sedang berlangsung sejak tahun 2011 hingga saat ini tentunya melibatkan masyarakat dan komunitas yang ada di Kota Magelang yang dilakukan dalam rangka mempromosikan Kota Magelang. Kegiatan ini seperti program AYO KE MAGELANG! yang setiap tahunnya diadakan dan pada tahun ini Program MONCER SERIUS, dimana pada kegiatan Program Moncer Serius dimaksudkan untuk memperkenalkan dan menonjolkan karakter masyarakat Kota Magelang yang Modern, Cerdas, Sejahtera dan Religius memberikan makna intrinsik baik bagi penyelenggara maupun masyarakat, terutama para wisatawan yang berkunjung.

Fenomena yang terjadi tersebut, memberikan sebuah proses pengetahuan yang timbul dari realitas yang ada, bagaimana seorang individu (masyarakat) memandang kegiatan ini sebagai kegiatan city branding Kota Magelang yang sedang berlangsung dan dilakukan secara berulang. Kemudian bagaimana masyarakat
Kota Magelang dan pemerintah Kota Magelang memaknai city branding Magelang Kota Sejuta Bunga di Kota Magelang. Selain itu bentuk sosialisasi yang diberikan oleh penyelenggara dalam hal ini pemerintahan yang memberikan berbagai himbauan kepada masyrakat untuk ikut serta dalam menyukseskan city branding Kota Magelang. Himbauan itu berupa wajib tanam tanaman di setiap rumah, dan instansi yang ada di Kota Magelang, wajib saling menjaga dan memelihara segala bentuk konstruksi city branding, dan sampaikan gagasan dan ide kepada pemerintahan mengenai city branding Kota Magelang. Fenomena yang terjadi tersebut, memberikan sebuah proses pengetahuan yang timbul dari realitas yang ada, bagaimana seorang individu atau masyarakat memandang dan memaknai maksud pemerintah dalam mewujudkan city branding Kota Magelang. Ragam makna timbul berasal dari masyarakat yang memaknai city branding MKSB di Kota Magelang. Masyarakat Kota Magelang memaknai city branding Kota Magelang dengan berbagai pendapat. Beberapa masyarakat membangun makna yang sama dengan pemerintah, namun hasil yang didapat setelah melaksanakan penelitian ditemukan bahwa masih banyak masyarakat Kota Magelang yang memaknai berbeda city branding yang dikonstruksi oleh pemerintah. Proses tersebut dapat dipahami melalui penjelasan Berger dan Luckman (Bungin, 2008: 15), yang mengatakan bahwa terjadi dialektika antara individu dalam menciptakan masyarakat dan masyarakat menciptakan individu. Proses dialektika ini terjadi melalui eksternalisasi, objektivasi, dan internalisasi. Proses dialektis mempunyai tiga tahapan, Berger menyebutnya sebagai momen. Dapat disimpulkan bahwa penjelasan Berger dan Luckman (Bungin, 2008) tersebut menilai realitas tidak dibentuk secara ilmiah, tidak juga sesuatu yang diturunkan oleh Tuhan, tetapi sebaliknya, dibentuk dan dikonstruksi. 
Penyelenggara atau pemerintah Kota Magelang melaksanakan city branding Kota Magelang MKSB dimulai dengan interaksi antara pihak-pihak yang terlibat dalam city branding Kota Magelang Sebagai Kota Sejuta Bunga dalam lingkup pemerintahan, yang kemudian diharapkan kerjasama berbagai pihak baik dari tataran pemerintahan, komunitas, masyarakat luas ataupun pihak-pihak luaryang membantu city branding tersebut. Kegiatan ini dapat dikatakan sebagai bagian dari proses eksternalisasi. Setelah dilakukannya interaksi melalui kerjasama yang terjadi antara pihak-pihak yang terlibat, menghasilkan sebuah pelaksanaan kegiatan yang didalamnya dirancang oleh pihak-pihak terkait kemudian disosialisaikan kepada masyarakat dan komunitas Kota Magelang dalam rangka city branding MKSB melalui event grebeg gethuk, karnaval, festival Gunung tidar dan event lainnya. Event-event tersebut melibatkan berbagai UKM, komunitas dan masyarakat luas Kota Magelang. Hal ini sejalan denga penelitian Fajrini, Bakti, dan Novianti (2018) bahwa dengan mengadakan event daerah maka meningkatkan city branding daerah tersebut sebagai perwujudan visi kota Sawahlunto.

Bentuk-bentuk interaksi yang dilakukan dapat berupa pertemuan tatap muka dan kegiatan terkait city branding MKSB Kota Magelang. Sehingga, dapat dikatakan bahwa hasil dari interaksi tersebut tergolong sebagai tahapan objektivasi. Seperti yang dijelaskan oleh Berger (Bungin, 2008), sesudah tahap eksternalisasi ini terjadi, maka proses selanjutnya adalah memasuki tahap objektivasi. Pihak-pihak yang terkait ini tidak hanya memahami definisi Kota Magelang sebagai Kota Sejuta Bunga melalui kegiatankegiatan yang dialami bersama, namun tiap individu mendefinisikan kenyataan-kenyataan itu secara timbal balik. Proses individu dalam memaknai kenyataan-kenyataan city branding Kota Magelang ini merupakan tahap Internalisasi.
Seperti yang dikemukakan Evadianti (2017: 33), dalam jurnal yang berjudul "Reposisi Brand dalam Festival Krakatau oleh Dinas Kebudayaan dan Pariwisata Provinsi Lampung”. Masyarakat merupakan pilar utama dalam pengembangan pariwisata, karena pada dasarnya pilar pariwisata itu terdiri dari pertama pemerintah, kedua swasta, ketiga masyarakat, yang sering disebut tiga pilar utama pariwisata. Kegiatan tersebut dapat dikatakan sebagai bagian dari proses internalisasi. Sehingga, teori konstruksi sosial atas realita ini dianggap relevan dalam membahas proses dialektika yang terjadi pada masyarakat Kota Magelang teerhadap city branding MKSB di Kota Magelang.

Pada penelitian Kavaratzis (2014) dengan penelitiannya yang berjudul "From city marketing to city branding: Towards a theoretical framework for developing city brands", penelitian yang menjadikan kota-kota Eropa sebagai obyek penelitian ini melihat ketidak selarasan terhadap asset Kota dan masyarakat sehingga menyarankan untuk menerapkan city branding dengan melihat unsur penting yaitu konstruksi, komunikasi pelaku city branding, dan pengelolaan citra kota. Penelitian Kavaratziz mendukung penelitian ini yang juga melihat secara realitas timbul ketidak selarasan sebuah makna yang dimaknai oleh pemerintah dengan yang dimaknai oleh masyarakat. Sedangkan hasil penelitian oleh Fallah (2017) dengan penelitiannya yang berjudul Konstruksi Sosial Pelaku Bisnis Destinasi Wisata Puncak Bogor atas City branding " $A$ Land Of Harmony") memiliki kesamaan pada penelitian ini. Kesamaan pada penelitian ini adalah sama-sama dihasilkan atau ditemukan ketidak selarasan dengan wujud perbedaan maksud dan perbedaaan masyarakat dalam memaknai branding, dalam penelitian ini makna yang diterima oleh masyarakat dan pada penelitian Fallah oleh pebisnis yang ada di area Bogor. 
Makna tersebut hadir dikarenakan proses internalisasi yang diterima dan proses obyektivasi yang dirasakan pada wujud dan suasana city branding MKSB yang timbul. Internalisasi yang diterima oleh beberapa masyarakat Kota Magelang adalah berdasarkan ungkapan pemerintah sendiri, nama kegiatan yang dibuat oleh pemerintah dan berdasarkan wujud Kota Magelang sehingga membentuk makna yang berbeda-beda pada masyarakat Kota Magelang. Proses obyektivasi yang dirasakan oleh masyarakat memperkuat pengetahuan yang telah didapat oleh masyarakat Kota Magelang.

Sugiarsono (2009) dalam membuat sebuah city branding, terdapat beberapa kriteria yang harus dipenuhi, diantaranya adalah attributes, message, differentiation, dan ambassadorship. Kota Magelang telah memenuhi kriteria menurut Sugiarsono tersebut, hal itu dapat dibuktikan sebagai berikut: Attributes, Kota Magelang masih dalam proses membentuk karakter, daya Tarik, gaya, dan personalitas kota, dalam prosesnya karakter Kota Magelang yang sejuk, bersih, nyaman dan indah mulai terlihat sebagai karakter Kota Magelang. Magelang membuktikan dengan mekarnya berbagai tanaman dan membuat daya tarik wisatawan bahkan media massa. City branding yang dibuat harus sesuai dengan karakter, serta potensi yang dimiliki oleh Kota, sehingga city branding yang dibuat dapat mewakili potensi dari Kota itu sendiri. City branding MKSB merupakan branding yang sesuai dengan potensi yang dimiliki oleh Kota Magelang, dengan hawa yang sejuk membuat tanaman yang ditanam di Kota Magelang tumbuh dan bermekaran dengan indah.

Message, pesan dari City branding Magelang Kota Sejuta Bunga adalah menggambarkan atau membuat sebuah taman dengan keindahan didalamnya untuk dinikmati baik warga Kota Magelang maupun wisatawan yang datang ke Kota Magelang. Selain suasana dan keindahan Kota Magelang, Kota Magelang juga menyuguhkan berbagai tawaran menarik lainnya seperti wisata gunung Tidar, wisata bermain, wisata kuliner, wisata religious, wisata pendidikan. Kota Magelang yang memiliki area kecil ini atau termasuk dalam Kota kecil ini, meskipun kecil namun memiliki berbagai macam hal yang dapat disuguhkan. Tidak hanya keindahgan dan kenyaman saja yang ditawarkan namun berbagai aktivitas didalamnya juga dapat dijadikan andalan oleh Kota Magelang.

Differentiation, keunikan yang dimiliki oleh Kota kecil ini adalah area wisata yang berada didalam Kota dan memiliki jarak yang tidak jauh dari pusat kota. Wisata yang menjadi pembeda dengan city branding yang telah ada sebelumnya dan pada kota lainnya adalah Kota Magelang yang dikenal sebagai kota kecil atau masuk dalam golongan Kota kecil ini memiliki wisata yang lengkap dalam satu area. Hal ini juga yang menjadi alasan Kota Magelang menduduki peringkat pertama untuk tiga kategori sekaligus, yakni Rating Kota Menuju Cerdas (Smart City), Rating Pengembangan dan Pengelolaan Kota dan Rating Kesiapan Integrasi (Inegration Readiness). Peringkat untuk kategori Smart City, Kota Magelang masuk kategori kota kecil dengan berpendudukan kurang dari dua ratus ribu, mengalahkan Bontang, Pariaman, Padang, Panjang dan ParePare. Sedangkan untuk rating Pengembangan dan Pengelolaan Kota, Kota Magelang bersanding dengan Surabaya (Kota besar) dan Samarinda (Kota sedang), dan bersanding dengan Semareanag (Kota besar) dan Samarinda (Kota sedang) untuk rating kesiapan Integrasi.

Ambassadorship, ambassador khusus yang ditunjuk sebagai ambasador Kota Magelang belum ada, namun pemerintah kota Magelang yakin dengan suasana nyaman, sejuk yang dimiliki oleh Kota Magelang dan guyup rukun masyarakat Kota Magelang dapat menjadi daya Tarik Kota Magelang, ditambah dengan berbagai macam destinasi wisata yang dimiliki oleh Kota Magelang. 


\section{Simpulan}

Berdasarkan tahapan yang telah peneliti lakukan mulai dari pengumpulan sampai pada pengolahan data, maka dapat ditarik kesimpulan bahwa city branding Magelang Kota Sejuta Bunga (MKSB) yang sedang dilaksanakan oleh Kota Magelang sejak tahun 2011 hingga saat ini memiliki latar belakang ide atau konsep berawal dari history Kota Magelang. Walikota Kota Magelang ingin memunculkan kembali kembali karakter lama pada jaman Belanda sebagai Tuin Van Java (Taman di Pulau Jawa), Paradijs Van Java (Surganya Pulau Jawa) dan Het Central Park Van Java (Taman di Tengah Pulau Jawa) kembali menjadi karakter bagi Kota Magelang.

Secara realitas peneliti melihat, pemerintah perlu meningkatkan kembali monitoring terhadap konstruksi-konstruksi sebagai wujud city branding MKSB Kota Magelang. Tidak hanya monitoring, pemerintah perlumemperhatikan dan membuat aturan yang ditujukan kepada seluruh masyarakat Kota Magelang mengenai wajib menjaga kelestarian lingkungan dan bersama menjaga dan merawat segala bentuk wujud yang telah dibangun untuk mewujudkan city branding MKSB di Kota Magelang. Strategi yang selama ini dilaksanakan oleh pemerintah perlu ditambah dengan menambahkan prioritas pada "Mengajak Seluruh Masyarakat Kota Magelang”.

Temuan pada penelitian ini adalah city branding MKSB di Kota Magelang baru bisa berjalan sesuai dengan rencana dan mewujudkan konsep Magelang dengan karakternya sebagai Magelang Kota Sejuta bunga adalah dengan memperhatikan kunci penting, yaitu perhatian, komunikasi dan kepedulian masyarakat. Pemerintah perlu memiliki strategi dalam menumbuhkan rasa kepedulian dan memperhatikan pendapat masyarakat terhadap city branding MKSB di Kota Magelang.

\section{Daftar Pustaka}

Aaker, David. (2001). Managing Brand Equity Capitalizing on the Value of a Brand Name. The Free Press, New York Anholt, S. (2007). Competitive Identity: The New Brand Management for Nation, Cities, and Regions. London: Palgrave MacMillan.

Bungin, B. (2008). Sosiologi Komunikasi (Teori, Paradigma dan Discourse Teknologi Komunikasi di Masyarakat). Jakarta: Kencana Prenada Media Group. Bungin, B. (2017). Konstruksi Realitas Brand Destinasi Wajah Manis Destinasi Pariwisata: Fakultas Ilmu Sosial dan Ilmu Politik Universitas Muhammadiyah Sidoarjo. 20-21.

Chaerani, R. Y. (2011). Pengaruh City Branding Terhadap City Image (Studi Pencitraan Kota Solo:'The Spirit of Java'). JRK, 2(4). Evadianti, Y. (2017). Reposisi Brand Dalam Festival Krakatau Oleh Dinas Kebudayaan Dan Pariwisata Provinsi Lampung. PRofesi Humas, 2(1), 23-36. https://doi.org/10.24198/prh.v2i1.10610 Fajrini, N., Bakti, I., \& Novianti, E. (2018). City Branding Sawahlunto Kota Wisata Tambang Yang Berbudaya Melalui Event Sawahlunto International Songket Carnival (SISCa) 2016. PRofesi Humas, 2(2), 169-185. https://doi.org/10.24198/prh.v2i2.12861

Fallah, M. N. (2017). Konstruksi Sosial Pelaku Bisnis Destinasi Wisata Puncak Bogor Atas City Branding Kabupaten Bogor "A Land Of Harmony" (Doctoral dissertation, Universitas Airlangga). Juanim, J., \& Rahmawati, N. L. (2015). Pengaruh City Branding terhadap Image of Urban Destination dan Dampaknya pada Post-Visit Behavior. TRIKONOMIKA, 14(1), 66-75. Kavaratzis, M. (2004). From City Marketing To City Branding: Towards A Theoretical Framework For Developing City Brands. Place Branding, 1(1), 58-73. 
Nas, d. P. J. M. (1986). Kota di Dunia Ketiga: Pengantar Sosiologi Kota. Jilid 1. Jakarta: Bhratara Karya Aksara. Noveline, K., Lestari, P., \& Susilo, M. E. (2014). Pembentukan Citra Perusahaan Melalui Ekuitas Merek (Studi Kasus Pada Majalah Kabare). Jurnal Ilmu Komunikasi, 7(2), 153-161. Quieqley, J.M. (2009). Urbanization, Aggromeration, and Economics Development. World Bank Report.
Rakhmat, J. (2001). Metode Penelitian Komunikasi. Bandung: PT. Remaja Rosdakarya. Sendjaja, S. Djuarsa. (1994). Teori Komunikasi. Jakarta: Universitas Terbuka Sugiarsono, J. (2009). City Branding Bukan Sekedar Membuat Logo dan Slogan. Majalah SWA. Jakarta. Sulaiman, A. (2016). Memahami Teori Konstruksi Sosial Peter L. Berger. Society, 4(1), 15-22. 